\title{
20303 乱流中のマイクロバブル溶解速度 Dissolution Rate of Microbubbles in Turbulent Flow
}

\author{
羽田 智信（東京農工大） 正 杉山 和靖（Twente 大） 正 亀田 正治（東京農工大） \\ 正 藤原 暁子（東京大） 正川島 久宜（海技研）正 菱田 公一（慶応大） 正 児玉 良明（海技研）
}

Tomonobu HANEDA, Tokyo University of Agriculture and Technology, Koganei, Tokyo 184-8588

Kazuyasu SUGIYAMA, The University of Twente, Langezijds A 122, P.O.BOX 217,7500 AE, Enschede, Netherlands

Masaharu KAMEDA, Tokyo University of Agriculture and Technology

Akiko FUJIWARA, The University of Tokyo, Bunkyo-ku, Tokyo 113-8656

Hisanobu KAWASHIMA, National Maritime Research Institute, Mitaka, Tokyo 181-0004

Koichi HISHIDA, Keio University, Kohoku-ku, Yokohama 223-8522

Yoshiaki KODAMA, National Maritime Research Institute

This paper deals with the dissolution of microbubble in a turbulent round jet. We took detailed experimental data of velocity field and bubble radius by time-resolved optical measurements. The velocity field of gas-liquid flow was measured by Particle Imaging Velocimetry-Laser Induced Fluorescence(PIV-LIF). The bubble radius was measured by Interferometric Laser Imaging(ILI). Experimental data of dissolution rate were compared with a correlation equation derived by Sugiyama et al.(2004), in which shearing motions of turbulent small eddies are taken into account. The dissolution process in the experiment shows good agreement with that predicted by the correlation equation.

Key Words: Bubble, Dissolution, Turbulent Jet, Particle Image Velocimetry, Particle Sizing, High-speed Photography

\section{1. 緒言}

マイクロバブルは溶解性が高く, 水質浄化装置, 養殖, $\mathrm{CO}_{2}$ の海洋隔離など, さまざまな分野で利用・研究されている(1). 気泡群の溶解挙動を予測するためには，個々の気泡の物質移 動速度を定量的に評価する必要がある。

半径 $R[\mathrm{~m}]$ の気泡表面に対して，単位時間・単位面積あた りの質量流束 $\dot{m}\left[\mathrm{~kg} /\left(\mathrm{s} \cdot \mathrm{m}^{2}\right)\right]$ は,

$$
\dot{m}=-\frac{S h D}{2 R}\left(C_{S}-C_{\infty}\right)
$$

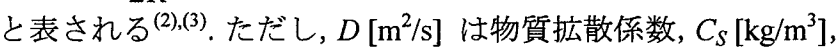

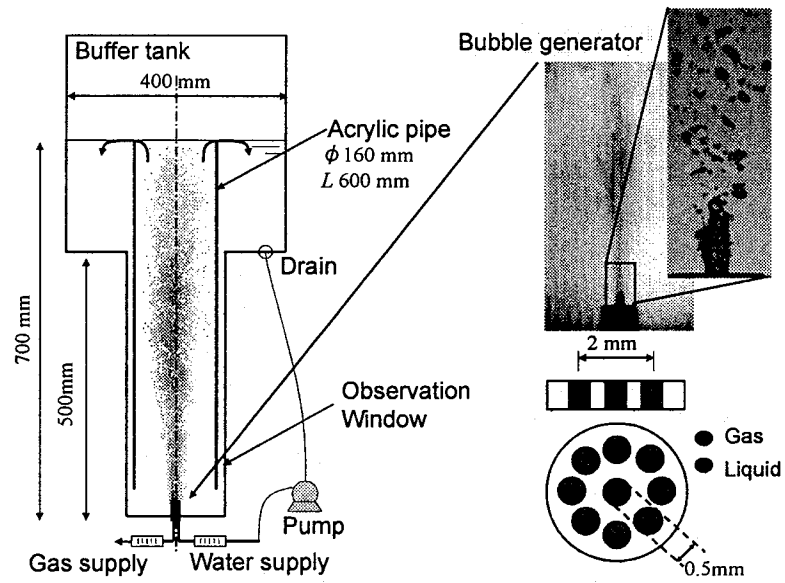

Fig. 1 Experimental apparatus
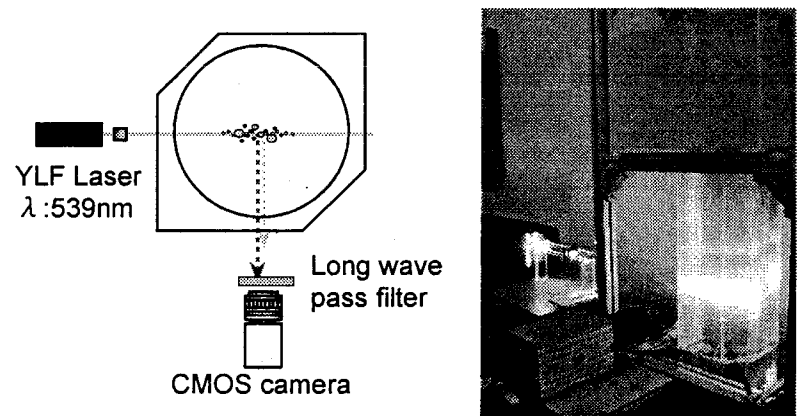

Fig. 2 Optical setup
$C_{\infty}$ はそれぞれ，気泡表面，無限遠方での溶存ガス濃度を表す． Sh [-] は Sherwood 数と呼ばれる物質移動量の指標である.Sh 数は, 気泡周りの溶存ガス濃度場に依存し, 濃度場は, 気泡 周りの流れ場の影響を強く受ける.

$S h$ 数のモデルとして，さまざまな相関式が提案されている. 例えば, 比較的高い Reynolds 数の層流中における単一上昇 気泡に対しては, Ranz-Marshall 則(3),(4)

$S h=2+0.6 S c^{1 / 3} R e^{1 / 2}, S c=v / D, R e=2 u_{B} R / v \cdot \cdots(2)$ が良く知られている.ただし $S c$ は Schmidt 数, $v$ は動粘度 $\left[\mathrm{m}^{2} / \mathrm{s}\right], u_{B}$ は気液のスリップ速度である。

式(2)の他にもさまざまな条件に対する相関式が提案され ている(2). しかし，式(2)も含めて，気泡周囲の強い乱れによ るせん断の影響が考慮されているものは皆無である.

最近，著者らは，気泡径が小さいほどせん断による溶解促 進が重要となることを理論的に示し，それと同時に，単純せ ん断流れの数值計算結果をもとに, 次の相関式を提案した ${ }^{(5)}$.

$$
S h=2+0.6 S c^{1 / 3} R e^{1 / 2}+1.055 S c^{1 / 3} \frac{\varepsilon^{1 / 4} R}{v^{3 / 4}}
$$

ただし， $\varepsilon\left[\mathrm{m}^{2} / \mathrm{s}^{3}\right]$ は乱れのエネルギ散逸率である.

本研究では，新たに提案した相関式(3)の検証実験を行う。 そのためには, 乱れを含む流れ場と気泡径の詳しい時閒履歴 が必要である．本研究では，高速度ビデオカメラを用いた画 像計測により，これらのデータを算出した．具体的には，軸 対称水噴流を対象として $\mathrm{CO}_{2}$ 気泡の溶解過程を調べた。 PIV/LIF 法による流れ場計測，ILI（Interferometric Laser Imaging）法による気泡径計測を行った.

\section{2. 実験装置・方法}

図 1 に実験装置の概略を示す.下部に気泡噴流発生装置を 取り付けたアクリル製の水槽である. 噴流の軸対称性を確保 するために, 水槽内部にはアクリル製の円筒 (内径 $160 \mathrm{~mm}$, 高さ $600 \mathrm{~mm}$ ）が挿入されている。これにより，噴流の直進 性を妨げる容器内流動の影響を排除することができる.また, 光学計測のため, 水槽外側は六角柱 (図 2) 形状をしている.

マイクロバブル噴流の発生には, 竹村ら ${ }^{(6)}$ の開発したノズ ルを用いた。 このノズルは，図 1 に示すとおり，1つの気体 供給孔の周りを 8 ヶ所の水供給孔が取り囲むものである. 水 噴流のせん断層によって, 気泡の微細化が促進される. 本装 
置により得られる気泡の典型的な半径は約 $150 \mu \mathrm{m}$ である. 光学系配置を図 2 に示す.レーザシート光を照射したマイ クロバブル噴流を，レーザ入射位置と直角に設置した高速度 ビデオカメラ（IDT, X-stream VISION model XS-3）によりよ らえた。光源には高周波パルス(YLF)レーザ (Photonics, DM10E-527，波長: $539 \mathrm{~nm}$ )を用いた。

液相速度場の計測は PIV/LIF 法 ${ }^{(7)} よ よ り$ 行った。トレーサ には, Rhodamine-B (吸収波長域: 460-550 nm; 蛍光波長域: 550-700 nm）を含む蛍光粒子（日本ペイント製, 粒径約 50 $\mu \mathrm{m} ） を$ 用いた．画像計測時には，カメラレンズ前面に長波 長透過フィルタを取りつけ，トレーサ粒子のみを撮影した。 また, PIV 画像は, 相互相関法（処理ソフトウェア:DITECT, Dipp-Flow V.1.20）によって解析した.

気泡径の計測は Maeda ら ${ }^{(8)}$ が開発した改良 ILI 法により 行った. ILI 法では，非焦点面に置かれたカメラを用いて， 気泡表面の反射光と気泡内を通過する屈折光によって得ら れる干渉縞をとらえる。干渉縞間隔と粒径との間に線形関係 が成り立つことを利用して気泡半径を算出する．なお，改良 ILI 法では, 撮影画像中の多数の気泡干渉縞像の重なりを防 ぐためのレンズ系がカメラ前面に取り付けられている.

\section{3. 実験結果と考察}

\section{1 実験条件}

実験条件を表 1 に示す．気体供給孔，8 個の水供給孔の出 口平均流速は，それぞれ， $1.27 \mathrm{~m} / \mathrm{s} ， 10.6 \mathrm{~m} / \mathrm{s}$ である。

\begin{tabular}{|c|c|}
\hline Supplied gas: & $\mathrm{CO}_{2}$ \\
\hline Flow rate of supplied gas: & $0.25[\mathrm{ml} / \mathrm{s}]$ \\
\hline Flow rate of supplied water: & $8.47[\mathrm{ml} / \mathrm{s}]$ \\
\hline Measurement height $(x)$ : & $100[\mathrm{~mm}]$ \\
\hline Water temperature: & $28.3 \pm 0.2\left[{ }^{\circ} \mathrm{C}\right]$ \\
\hline Dissolved oxygen concentration: & $<1.3\left[\mathrm{~g} / \mathrm{m}^{3}\right]$ \\
\hline
\end{tabular}

本実験では, 溶存ガス濃度の違いによる溶解特性の変化を 抑え，実験の再現性を高めるために，実験毎に真空ポンプを 用いて媒質を脱気した。脱気後の溶存酸素濃度 $\left(1.3 \mathrm{~g} / \mathrm{m}^{3}\right)$ は飽和濃度の $3.5 \% に$ 相当する. また，一回の実験時間（約 10 秒）に供給される $\mathrm{CO}_{2}$ 質量 $(5 \mathrm{mg})$ は，実験に用いる水 全量 $(43 \mathrm{l})$ に対する飽和質量 $(59 \mathrm{~g})$ に比べて十分小さく, 噴流による $\mathrm{CO}_{2}$ バルク濃度の増加は無視することができる.

ノズル上方 $100 \mathrm{~mm}$ 付近の流れ場, 気泡径を画像計測した。 液相速度場の計測では，撮影速度 $1,600 \mathrm{fps}$ (サンプリング 閒隔 $0.625 \mathrm{~ms}$ ), 空間解像度 $60 \mu \mathrm{m} / \mathrm{pixel}$ のもとで, $128 \times 1,024$ pixels の領域を撮影した. 160,000 枚の時系列データを取得し， PIV 法により速度ベクトルを算出し, 乱流統計量を求めた. 速度べクトルの算出間隔は $20 \times 20$ pixels，ベクトル算出のた めの検査領域は $29 \times 29$ pixels である.

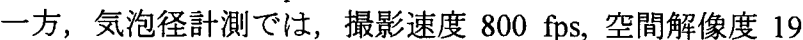
$\mu \mathrm{m} / \mathrm{pixel}$ のもとで, $1,000 \times 800$ pixels の領域を撮影した．同定 可能な気泡 150 個を選び, 半径時間変化を算出した。

\section{2 液体流れ場の性質}

実験から得られたノズル上方 $100 \mathrm{~mm}$ における噴流の平均 流速 $U_{m}$ は $0.67 \mathrm{~m} / \mathrm{s}$, エネルギ散逸率 $\varepsilon$ は $0.44 \mathrm{~m}^{2} / \mathrm{s}^{3}$ であった.

エネルギ散逸率をもとに乱れの最小スケール (Kolmogorov スケール）を評価すると，時間スケール $\tau_{\eta}\left[=(v / \varepsilon)^{1 / 2}\right]=1.4 \mathrm{~ms}$, 長さスケール $\eta\left[=\left(v^{3} / \varepsilon\right)^{1 / 4}\right]=34 \mu \mathrm{m}$ となる.これらの值を PIV 計測条件と比較すると，撮影サンプリング間隔は $\tau_{\eta}$ に比べて 十分短いが, 空間解像度はれより粗い

空間解像度の粗さはエネルギ散逸率算出の誤差につなが る，そこで，同じシステムを用いて行った円筒自由噴流を計 測したところ，信頼できる実験結果 ${ }^{(9)} に$ 比べてエネルギ散逸 率は $1 / 2$ 程度となった。 今回示した計測データでもエネルギ 散逸率は同程度に過小評価されていると考えられる。

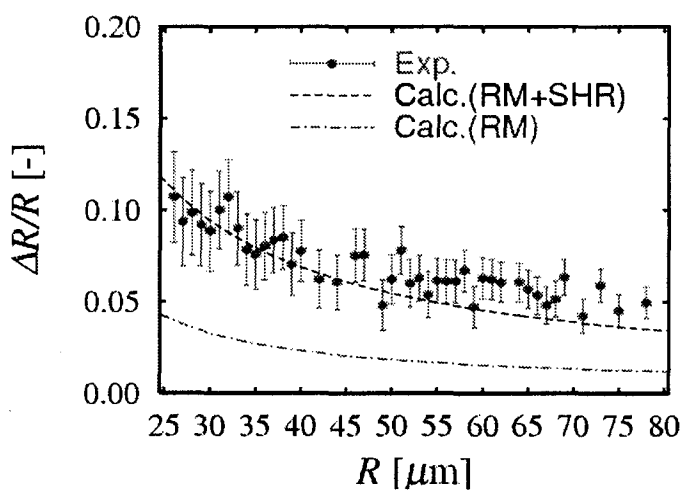

Fig. 3 Dissolution rate

\section{3 相関式との比較}

溶解速度の実測値を $2 つ の$ 相関式(2), (3)と比較したものを 図 3 に示す．実測值は，ノズル上方 $100 \mathrm{~mm}$ 付近を $7.5 \mathrm{~mm}$ 上昇する間の気泡半径変化率 $(\Delta R / R)$ である. また, エラー バーは ILI 法計測にともなう誤差 $(0.34 \mu \mathrm{m})$ を表している. 一方，理論值は，実験条件に合わせるため，

$$
\frac{d R}{d x} \approx \frac{1}{U_{m}+u_{B}} \frac{d R}{d t}=S h \frac{D\left(C_{S}-C_{\infty}\right)}{2 \rho_{G} R\left(U_{m}+u_{B}\right)}
$$

を数值積分することで算出した.ただし， $\rho_{G}$ は 1 気圧下での $\mathrm{CO}_{2}$ ガス密度 $\left(=1.76 \mathrm{~kg} / \mathrm{m}^{3}\right), D$ は水中での $\mathrm{CO}_{2}$ 拡散係数 $\left(=1.8 \times 10^{-9} \mathrm{~m}^{2} / \mathrm{s}\right), C_{S}$ は 1 気圧における水の $\mathrm{CO}_{2}$ 飽和濃度 $\left(=1.34 \mathrm{~kg} / \mathrm{m}^{3}\right), C_{\infty}$ は水中の $\mathrm{CO}_{2}$ バルク濃度 $(=0)$ である. また，スリップ速度 $u_{B}$ は Stokes 則から求めた。

図 3 より，実験值は，Ranz-Marshall 則[式(2), RM]に比べて 3 倍程度溶解速度が大きいことが分かる. また, その值は, 乱流影響を含む相関式(3)(RM+SHR)に良く一致している.

比較的大きな気泡 $(R>40 \mu \mathrm{m})$ では, 実験値の溶解速度が 相関式(3)に比べて大きくなっている。これは，前述のエネル ギ散逸率の過小評価によると思われる. 小さいサイズの気泡 では，微量に残留する液体中の空気が $\mathrm{CO}_{2}$ の溶解を妨げ，見 かけ上相関式(3)ときわめて良く一致している可能性がある. しかし，エネルギ散逸率の見積もり誤差や残留空気が溶解速 度に与える影響は $10 \%$ 程度であり，本実験の結論である「乱 流影響による有意な溶解促進効果」を摇るがすものではない，

\section{4. 結論}

乱流によるマイクロバブル溶解促進効果を実験的に調べ た. 水噴流中の $\mathrm{CO}_{2}$ 気泡を対象として, PIV-LIF 法による速 度場計測, ILI 法による気泡径計測を行った。実験值を $2 つ$ の溶解速度相関式と比較した。

実験値は，乱流影響を含まない相関式(2)に比べて，有意に 大きな溶解速度を示した，また，その值は，著者らが新たに 導出した相関式(3)と良く一致することがわかった。

\section{参考文献}

(1) 大成博文他 3 名, 日本混相流学会誌 16 (2002), 130-137.

(2) Clift, R., Grace, J.R. and Weber, M.E., Bubbles, Drops and Particles (1978), Academic Press.

(3) Bird, R.B., Stewart, W.E. and Lightfoot, E.N., Transport Phenomena, (1960), Wiley.

(4) Ranz, W.E. and Marshall, W.R., Chem. Eng. Prog. 48 (1952), 141-146, 173-180.

(5) 杉山和靖他 6 名，日本機械学会流体工学部門講演会講演論文集 (2004), Paper No. 815

(6) 竹村文男 - 松本洋一郎, 特許 2000-392677 (2000).

(7) Tokuhiro, A., et al. Trans. ASME J. Fluids Eng. 121 (1999), 191-197.

(8) Maeda, M., et al., Meas. Sci. Technol. 11 (2000), L13-L18.

(9) Panchapakesan, N.R. and Lumley, J.L., J. Fluid Mech. 246 (1993), 197-223. 